Countries from $\mathrm{N}$ ew V accines A gainst Enteric Infections. Conference Report of the Swedish Academy for Research and Cooperation in Developing Countries; 1990.

6. Di Matteo A, Sarasini A, Scotta MS, Parea M, Licardi G, Gerna G. Nosocomial outbreak of infant rotavirus diarrhea due to the appearance of a new serotype 4 strain. J M ed Virol 1989;27:100 104.

7. Bartlett AV, Reves RR, Pickering L. Rotavirus in infant-toddler daycare centers: epidemiology relevant to disease control strategies. J Pediatr 1988:113:435-441.

8. Keswick BH, Pickering LK, DuPont HL, Woodward WE. Survival and detection of rotaviruses on environmental surfaces in daycare centers. Appl Environ Microbiol 1983:46:813-816.

9. Matsumoto K, Hatano M, Kobayashi K, et al. An outbreak of gastroenteritis associated with acute rotaviral infection in schoolchildren. J Infect D is 1989;160:611-615.

10. Lewis DC, Lightfoot NF, Cubitt WD, Wilson SA. Outbreaks of astrovirus type 1 and rotavirus gastroenteritis in a geriatric in-patient population. $J$ H osp Infect 1989; 14:9-14.

11. Holzel H, Cubitt DW, McSwiggan DA, Sanderson PJ, Church J. An outbreak of rotavirus infection among adults in a cardiology ward. I Infect 1980;2:33-37.

12. Yolken RH, Bishop CA, Townsend TR, et al. Infectious gastroenteritis in bone-marrow-transplant patients. $\mathrm{N}$ Engl $J$ Med 1982;306:1009-1012.

13. Sattar SA, Lloyd-Evans N, Springthorpe VS, Nair RC. Institutional outbreaks of rotavirus diarrhea: potential role of fomites and environmental surfaces as vehicles for virus spread. $J \mathrm{H} \mathrm{yg}$ 1986:96:277-289

14. Ward RL, Bernstein DI, Knowlton DR, et al. Prevention of surface-to-human transmission of rotavirus by treatment with disinfectant spray. J Clin Microbiol 1991;29:1991-1996.

15. Samadi AR, Haq MI, Ahmed QS. Detection of rotavirus in handwashings of attendants of children with diarrhoea. $\mathrm{Br} \mathrm{Med} J$ 1983;286:188

16. Pickering LK, Bartlett AV, Woodward WE. Acute infectious diarrhea among children in daycare: epidemiology and control. Rev Infect $\mathrm{D}$ is 1986;8:539-547.

17. Ansari SA, Sattar SA, Springthorpe VS, Wells GA, Tostowaryk W. Rotavirus survival on human hands and transfer of infectious virus to animate and nonporous inanimate surfaces. J Clin Microbiol 1988;26:1513-1518.

18. Lloyd-Evans N, Springthorpe VS, Sattar SA. Chemical disinfection of human rotavirus-contaminated inanimate surfaces. $J$ Hyg 1986:97:163-173

19. U.S. Environmental Protection Agency. Efficacy D ata Require ments for Virucides. Washington. DC: Office of Pesticide Programs; Environmental Protection Agency; 1979: document no. DIS/TSS-7.

20. American Public Health Association. Standard M ethods for the Examination of Water and Wastewater. Washington, DC: American Public Health Association; 1992.

21. Ansari SA, Sattar SA, Springthorpe VS, Wells GA, Tostowaryk $\mathrm{W}$. In vivo protocol for testing the efficacy of hand-washing agents against viruses and bacteria: experiments with human rotavirus and Escherichia coli. Appl Environ Microbiol 1989;55:3113-3118.

22. Ansari SA, Springthrope VS, Sattar SA. Survival and vehicular spread of human rotaviruses: possible relation to seasonality of outbreaks. Rev Infect D is 1991;13:448-461.

23. Ward RL, Bernstein DI, Young EC, Sherwood JR, Knowlton DR, Schiff GM. Human rotavirus studies in volunteers: determination of infectious dose and serological response to infection. $J$ Infect Dis 1986;154:871-880.

24. Black RE, Dykes AC, Anderson KE, et al. Handwashing to prevent diarrhea in day-care centers. Am J Epidemiol 1981;113:445451.

25. Hadler SC, McFarland L. Hepatitis A in daycare centers: epidemiology and prevention. Rev Infect Dis 1986;8:548-557.

26. Rutala WA. APIC guidelines for selection and use of disinfectants. Am J Infect Control 1990;18:99-117.

\title{
Infectious Disease Specialists Did Not Wash Hands When Leaving Restroom
}

\section{by Gina Pugliese, RN, MS Medical News Editor}

Researchers from the New Orleans Department of Health and Tulane University School of Medicine recently reported the handwashing activities of 493 consecutive persons using public restrooms during the 1993 Infectious Disease Society of America annual meeting. Only $67.7 \%$ of those observed washed their hands before leaving the restroom area. Female meeting attendees were more likely to wash $(86.6 \%)$ than were their male counterparts $(56.4 \%)$
FROM: Plotkin S, Charles A, Adam $C$, et al. Handwashing and restrooms: do infectious disease experts practice what they preach? Presented at the 34th Interscience Conference on Antimicrobial Agents and Chemotherapy; October 4-7, 1994; Orlando, Florida. Abstract F156. 